\title{
PENGELOLAAN DIRI SEBAGAI UPAYA MEMBANGUN KERJA SAMA DALAM PERTUKARAN PELAJAR DI PERGURUAN TINGGI
}

\author{
Anita Eka Ramadhani ${ }^{1}$, Aulia Yogi Septia ${ }^{2}$, Ririn Wijayanti ${ }^{3}, \&$ \\ Arina Septianingtias ${ }^{4}$ \\ e-mail: ramadhanianitaeka@gmail.com ${ }^{1}$, aulyogy@gmail.com², \\ ririn14wijayanti@gmail.com ${ }^{3}$, arinaseptia123@gmail.com ${ }^{4}$ \\ Pendidikan Guru Sekolah Dasar, FKIP, Universitas Sebelas Maret
}

Jalan Ir. Sutami Nomor 36, Kentingan, Kec. Jebres, Kota Surakarta, Jawa Tengah 57126

\begin{abstract}
Abstrak: Masa pandemi saat ini mendorong seluruh bidang dan kegiatan di dalamnya dilakukan secara daring ataupun virtual, termasuk pada pelaksanaan program pertukaran pelajar. Penelitian ini bertujuan untuk mengetahui pentingnya Pengelolaan diri untuk membangun kerja sama pada program pertukaran pelajar di perguruan tinggi secara virtual. Teknik pengumpulan data yang digunakan yaitu teknik observasi partisipasi dan wawancara terstruktur. Partisipan dalam penelitian ini adalah 20 mahasiswa PGSD semester 5 pada dua perguruan tinggi negeri di Jawa, yang mengikuti kegiatan pertukaran pelajar antar program studi di perguruan tinggi yang berbeda. Pengumpulan data menggunakan wawancara, dengan pedoman yang didasarkan pada parameter mengenai pengelolaan diri dan kerja sama. Analisis terhadap hasil wawancara diperkuat dengan pengamatan karena peneliti terlibat langsung dalam keseharian orang yang sedang menjadi objek penelitian. Teknik analisis data yang digunakan adalah model Miles dan Huberman yang terdiri atas aktivitas data reduction, data display, dan drawing/ verification. Hasil penelitian menunjukkan tiap partisipan sudah memiliki Pengelolaan diri yang baik, ditunjukkan dengan cara mengatasi berbagai masalah kerja sama tim secara virtual dengan pengelolaan diri, cara membagi waktu, prioritas dan komunikasi yang baik, sehingga tercipta kerja sama tim yang baik. Pengelolaan diri yang baik akan menciptakan kerja sama tim yang baik pula, begitupun sebaliknya.
\end{abstract}

Kata-kata Kunci: kerja sama, pengelolaan diri, pertukaran pelajar

\section{SELF-MANAGEMENT TO BUILD SOLID TEAMWORK ON THE STUDENT EXCHANGE PROGRAMS IN HIGHER EDUCATIONS}

\begin{abstract}
The current pandemic has prompted all fields and activities to be carried out online or virtually, including the implementation of student exchange programs. The research aims to determine the importance of self-management in building solid teamwork between students in exchange programs virtually. Data collected through structured interviews and participatory observation. Participants are 20 students of the 5 th semester in Primary teacher education (PGSD) from two universities in Java that follow Student Exchange Programs in Kampus Merdeka-Merdeka Belajar. Interview data were collected and classified according to interview guidelines based on self-management and solid teamwork indicators. The interview results were confirmed with direct observation by the researcher involved in the daily activities of research participants. The data analysis uses the Miles and Huberman model that consists of data reduction, data display, and drawing/verification activities. The results revealed that each participant experienced difficulties building virtual teamwork in terms of internet networks, individual interests, et cetera. Participants also carry out self-management to work together in teams by setting time, priorities, and other related to their performance to complete group tasks.
\end{abstract}

Keywords: self-management, student exchange, teamwork 


\section{PENDAHULUAN}

Revolusi industri merupakan sebuah perubahan holistik di berbagai bidang kehidupan manusia, seperti pertanian, transportasi, teknologi dan sebagainya. Perubahan di semua bidang tersebut akan berdampak pada kondisi ekonomi, sosial, dan budaya yang ada di seluruh penjuru dunia, salah satunya Indonesia. Sumber daya manusia yang berkualitas harus dipersiapkan untuk menghadapi tantangan perubahan zaman. Menurut Noe dalam Khoiriyah (2011) terdapat empat tantangan dalam perubahan zaman, yaitu tantangan yang berhubungan dengan kualitas, tantangan global, tantangan sosial dan tantangan sistem kerja berkinerja tinggi. Semua elemen masyarakat harus berupaya menghadapi tantangan tersebut, salah satunya mahasiswa.

Mahasiswa berperan sebagai agent of change dan social control yaitu perubahan menuju ke arah yang lebih baik dan akan memberikan manfaat serta menjadi pengontrol untuk dirinya sendiri, orang tua, teman-teman, orang-orang di sekitarnya dan untuk negara (Apriyani, 2019). Pentingnya peran mahasiswa dalam kelangsungan kehidupan berbangsa dan bernegara, membuat pemerintah berupaya untuk mempersiapkan mahasiswa dalam menghadapi tantangan perubahan zaman melalui peningkatan kompetensi secara matang yang disesuaikan dengan kebutuhan zaman.

Oleh karena itu, Menteri Pendidikan dan Kebudayaan mengeluarkan kebijakan Merdeka Belajar- Kampus Merdeka yang meliputi hak belajar tiga semester di luar program studi yang bertujuan untuk meningkatkan kompetensi lulusan, baik soft skills maupun hard skills dan menyiapkan lulusan sebagai pemimpin bangsa yang unggul dan berkepribadian (Kemendikbud, 2020). Salah satu program yang disediakan dalam Merdeka BelajarKampus Merdeka ialah pertukaran pelajar. Menurut Sun Education Group (2020) pertukaran pelajar adalah program yang memungkinkan siswa sekolah atau mahasiswa untuk merasakan pengalaman belajar di sekolah atau universitas lain. Program pertukaran pelajar dapat terlaksana atas kerja sama kedua sekolah atau universitas maupun diselenggarakan pihak ketiga yang menyediakan fasilitas.

Pertukaran pelajar diselenggarakan untuk membentuk beberapa sikap mahasiswa yang termaktub di dalam Peraturan Menteri Pendidikan dan Kebudayaan (Permendikbud) Nomor 3 Tahun 2020, yaitu menghargai keanekaragaman budaya, pandangan, agama, dan kepercayaan, serta pendapat atau temuan orisinal orang lain; serta bekerja sama dan memiliki kepekaan sosial serta kepedulian terhadap masyarakat dan lingkungan (Kemendikbud, 2020).

Pertukaran pelajar dalam Merdeka BelajarKampus Merdeka dibedakan menjadi tiga, yaitu: (1) pertukaran pelajar antar prodi pada kampus yang sama, (2) pertukaran pelajar dalam prodi yang sama pada kampus yang berbeda, dan (3) pertukaran pelajar antar prodi pada kampus yang berbeda. Berdasarkan hal tersebut, pertukaran pelajar yang dilakukan oleh pihak dua universitas di Jawa merupakan pertukaran pelajar dalam prodi yang sama pada kampus yang berbeda. Menurut Kemendikbud (2020) bentuk pembelajaran yang diambil mahasiswa digunakan untuk memperkaya pengalaman dan konteks keilmuwan yang didapat di perguruan tinggi lain yang mempunyai ciri khas atau wahana penunjang pembelajaran untuk mengoptimalkan capaian pembelajaran. Pembelajaran dalam pertukaran pelajaran ini dilakukan secara dalam jaringan (online) yang meliputi dua mata kuliah dengan bobot 2 SKS dan 3 SKS.

Pertukaran pelajar yang diikuti oleh beberapa mahasiswa dengan latar belakang yang berbeda menyebabkan pembelajaran kurang efektif dan efisien. Perbedaan sosial, ekonomi, dan budaya antar mahasiswa menimbulkan perbedaan penafsiran dalam berkomunikasi sehingga berdampak pada kelangsungan teamwork. Menurut Lagu (2016) interaksi secara langsung maupun menggunakan media dari dua individu yang berbeda latar belakang sosial budaya sering terjadi kesalahpahaman dalam penafsiran makna yang disebabkan karena masingmasing memiliki latar belakang sosial, ekonomi, dan budaya yang berbeda sehingga mempengaruhi keefektifan dalam melakukan komunikasi. Apabila komunikasi dalam tim tidak berjalan dengan baik, maka akan menghambat proses pengerjaan tugas. Selain itu, culture kedua perguruan tinggi yang berbeda dalam pemberian tugas membuat mahasiswa sering kebingungan. Oleh karena itu, dibutuhkan self management untuk memperkuat solid teamwork. Self management atau pengelolaan diri sendiri harus ditanamkan pada mahasiswa untuk belajar bertanggung jawab dalam sebuah kerja kelompok atau teamwork.

Pada penelitian ini, pentingnya Pengelolaan diri untuk membangun solid teamwork dalam rangka pelaksanaan program pertukaran pelajar di perguruan tinggi secara virtual. Diharapkan mahasiswa dapat mencapai kompetensi yang diharapkan, memiliki self 
management yang baik serta menambah wawasan dan relasi. Penelitian ini memberikan gambaran betapa pentingnya self management pada diri setiap individu dalam membentuk kekuatan kerja sama atau solid teamwork yang dalam hal ini dilakukan pada program pertukaran pelajar di perguruan tinggi secara dalam jaringan.

Setiap individu dalam melakukan suatu aktivitas tentu menginginkan tujuan dan harapannya dapat tercapai dengan baik. Tercapainya tujuan tersebut dapat dilakukan jika pada diri individu tersebut mampu mengelolanya secara maksimal baik dari dalam dirinya ataupun dari luar. Hal itu dapat disebut dengan self management. Self management atau yang disebut juga dengan pengelolaan diri adalah kemampuan bekerja secara efektif untuk mencapai tujuan, dan menjadi fleksibel dalam menghadapi kemunduran. Definisi ini mencerminkan perencanaan dan upaya mengejar tujuan. Selain hal tersebut, definisi ini mencerminkan ketahanan dalam menghadapi dan mengatasi masalah selama mencapai tujuan, dalam hal ini adalah pengambilan keputusan, fokus, perencanaan, penjadwalan, pelacakan tugas, evaluasi diri, intervensi, pengembangan diri (Kadiyono \& Hafiar, 2017). Briesch dan Daniels (2013) menerangkan bahwa self management adalah kemampuan seseorang untuk mengendalikan emosi dan perbuatannya dengan jujur serta integritas dalam penyesuaian berbagai hal.

Sedangkan menurut Elvina (2019) self management adalah prosedur dimana individu mengatur perilakunya sendiri. Dengan demikian, self management atau manajemen diri adalah cara individu untuk mengelola atau mengatur perilakunya dalam menghadapi suatu aktivitas agar dapat melaksanakannya secara efektif dan efisien.

Self management memiliki beberapa aspek dalam pelaksanannya. Menurut Maxwell et. al (2014), self management atau manajemen diri memiliki tiga aspek yaitu pengelolaan waktu, hubungan antar manusia dan pespektif diri. Pengelolaan waktu berkenaan dengan penentuan penggunaan waktu agar dapat dimanfaatkan secara efektif dan efisien. Hubungan antar manusia dalam hal ini merupakan ikatan tiap individu dengan orang lain yang sangat mempengaruhi capaian seseorang dalam melakukan suatu aktivitas karena dengan hubungan yang baik maka kinerja seseorang juga akan optimal. Sedangkan perspektif diri adalah tanggapan atau penerimaannya dalam melihat diri sendiri dengan penglihatan orang lain terhadapnya sehingga seseorang dapat menilai dirinya secara luas. Apek-aspek tersebut perlu diperhatikan dalam melakukan manajemen diri yang tentu akan berdampak pada keberhasilan seseorang melakukan kegiatannya.

Dalam pelaksanaan self management atau manajemen diri ini dapat dilakukan dalam berbagai bidang termasuk pula dalam belajar. Gie (Jazimah, 2015) menyatakan bahwa self management dalam belajar ini dilakukan melalui beberapa hal untuk mencapai tingkat manajemen diri dalam belajar yang tinggi yaitu self motivation, self organization, self control dan self development. Self motivation atau motivasi diri beorientasi pada hasil dan mengejar tujuan melebih apa yang dibutuhkan, dimana orang yang dapat memotivasi diri akan menetapkan tujuan menantang untuk diri sendiri dan orang lain; mencari cara untuk meningkatkan kinerja; dan siap membuat pengorbanan pribadi untuk mencapai tujuan organisasi (Nurwendah \& Suryanto, 2019).

Menurut Rosmilawati (2017), self organization atau penyusunan diri adalah kemampuan menghubungkan ide, sikap, perasaan, dan perilaku untuk mengatur diri sendiri membentuk pribadi yang mampu menjalankan tugas dengan tepat. Self control atau pengendalian diri adalah kemampuan seseorang untuk menunda kepuasan langsung berupa imbalan yang lebih kecil untuk imbalan yang lebih besar nanti (Gillebaart, 2018). Sedangkan self development atau pengembangan diri adalah suatu perilaku untuk mengembangkan kualitas individu dalam berbagai bidang (Aboalshamat, 2014). Pengembangan diri dalam belajar ini dapat ditunjukkan dengan kepribadiannya, nilai sosial pada dirinya, kecerdasan dalam berpikir dan pemeliharan jasmani serta rohaninya.

Self management dalam belajar dilakukan agar tiap individu mampu mengatur dirinya dalam melakukan perilaku belajar sehingga seluruh kegiatannya mampu ia lakukan dengan baik. Kanfer (Fatchurahman, 2017) mengemukakan beberapa ciriciri individu yang memiliki self management yang tinggi yaitu goal setting, self monitoring, evaluasi diri dan self reinforcement. Goal setting atau menentukan sasaran artinya menetapkan tujuan utama seseorang melakukan kegiatan belajar sehingga hal yang dilakukannya menjadi terarah pada tujuan yang ingin dicapai. Selfmonitoring atau memantau dirinya sendiri di mana ia melakukan hal yang menjadikan hasil dari aktivitasnya tersebut sebagai umpan balik dan memperkuat sesuatu yang ada pada dirinya. Hal yang dapat dilakukan adalah menyusun catatan, membuat gambar dari data hasil penglihatannya, dan sebagainya. Evaluasi diri memiliki arti bahwa seseorang menilai rencana kerja dirinya apakah tujuannya dapat tercapai, 
apakah tugas yang dikerjakan dapat memenuhi batas waktu, dan sebagainya. Sedangkan self reinforcement atau penguatan diri merupakan cara individu untuk menghargai dirinya yang dimaksudkan untuk memberikan penghargaan pada dirinya atas pencapaian yang telah dilakukan.

Adanya self management atau pengelolaan dirinya terhadap suatu hal ini akan berguna agar suatu kegiatan dapat dilakukan oleh tiap individu secara efektif dan maksimal dalam proses pelaksanaannya. Terdapat beberapa faktor yang mempengaruhi self management dalam belajar antara lain perhatian terhadap waktu, kondisi sosial, tingkat kondisi ekonomi, tingkat pendidikan dan kendala lingkungan sekitar.

Perhatian terhadap waktu dilakukan dengan mengatur waktu dalam melakukan kegiatan belajar agar lebih teratur dan lancar seperti yang diharapkan. Kondisi sosial yang kondusif akan mendorong self management yang baik pula pada diri individu, jika hubungan antar individu baik, maka akan terbentuk self management yang baik pula. Tingkat kondisi ekonomi mempengaruhi self management dalam hal pemenuhan keperluannya, jika barangbarang yang dibutuhkan dalam belajar dapat terpenuhi dengan baik maka individu tersebut dapat menyelesaikan tugasnya dengan maksimal. Seseorang yang memahami pentingnya self management dalam belajar maka ia akan memiliki kemampuan belajar yang baik. Lingkungan sekitar juga mempengaruhi self management dalam hal pembentukan pola pikir, terbentuknya pengalaman dan munculnya perilaku. Semua faktor yang memengaruhi self management dalam belajar ini harus diperhatikan agar harapan dari proses belajar dapat terwujud.

Tim adalah sekelompok orang yang terdiri atas lebih dari dua orang yang saling berkomunikasi dan berkoordinasi untuk mencapai suatu tujuan yang sama. Untuk mencapai suatu tujuan yang akan dicapai kerja sama antar individu dalam tim harus dilakukan dengan baik. Aspek individu mempengaruhi kerja sama dalam tim, harus ada kesadaran bahwa tujuan yang akan dicapai bukan tujuan individu tetapi tujuan kelompok.

Kerja sama tim (teamwork) dapat secara akurat didefinisikan sebagai sekelompok individu yang bekerja secara kooperatif untuk mencapai tugas atau tujuan tertentu (Sanyal \& Hisam, 2018). Kerja sama tim sangat diperlukan dalam sebuah organisasi, dengan adanya kerja sama seseorang dapat saling bertukar pikiran dan saling mengingatkan untuk menyelesaikan tugasnya dengan baik. Kerja sama tim ini efektif untuk meningkatkan semangat dan menghasilkan output yang lebih baik daripada output individual.

West dalam Setyarini (2017) menyatakan ada empat kekuatan dalam membangun tim yang efektif, yaitu: kelompok mempunyai tugas-tugas yang menarik secara intrinsik agar berhasil, individu merasa dirinya penting dalam nasib kelompok, kontribusi individual sangat dibutuhkan, dan tim memiliki tujuan yang jelas dengan umpan balik yang tetap. Tugas-tugas yang yang sesuai dengan minat dan bakat anggota kelompok akan membuat anggota kelompok menjadi semangat dan bekerja keras untuk menyelesaikan tugas tersebut. Dalam sebuah tim setiap individu dalam tim memiliki peran masingmasing dan saling ketergantungan satu sama lain. Setiap anggota tim ikut serta dalam pengampilan keputusan dan mengetahui tujuan yang akan dicapai dengan jelas.

Manurung dalam (Kusuma \& Sutanto, 2018) mengemukakan bahwa indikator-indikator kerja sama tim adalah kerja sama, kepercayaan dan kekompakan. Kerja sama yang dilakukan oleh tim lebih efektif dan menghasilkan output yang lebih baik daripada kerja individu. Kepercayaan terhadap anggota dalam tim terhadap apa yang dikatakan dan yang dilakukan. Menurut Banwo (2015) kekompakan dalam suatu kelompok merupakan cerminan dari tingkat komunikasi dan keterikatan antar anggota kelompok dalam menghasilkan tugas, komitmen, peran, kebanggaan kelompok dan ketertarikan interpersonal. Jadi kerja sama yang baik terjadi apabila terdapat kerja sama, kepercayaan dan kekompakkan dalam suatu tim.

\section{METODE PENELITIAN}

Penelitian ini menggunakan metode penelitian survei, yang dilaksanakan di Program Studi Pendidikan Guru Sekolah Dasar (PGSD) Universitas Sebelas Maret Surakarta dan Universitas Negeri Yogyakarta. Partisipan penelitian ini adalah mahasiswa PGSD semester 5 kedua perguruan tinggi tersebut yang mengikuti kegiatan Merdeka Belajar-Kampus Merdeka Pertukaran Pelajar antar Program Studi pada Perguruan Tinggi yang berbeda, sebanyak 20 orang. Penelitian ini dilaksanakan pada jangka 3 bulan (September sampai dengan November 2020).

Fokus penelitian ini adalah self management mahasiswa yang berkaitan dengan terbentuknya solid teamwork antar mahasiswa selama perkuliahan yang dilakukan secara virtual. Untuk memperoleh data 
guna mengetahui hasil penelitiannya dilakukan teknik pengumpulan data yaitu teknik observasi partisipasi dan wawancara terstruktur. Observasi partisipan yaitu proses pengamatan di mana peneliti terlibat langsung dalam kegiatan orang yang diamati sebagai sumber data. Observasi partisipan ini dilakukan dengan keikutsertaan dalam program pertukaran pelajar tersebut, sehingga dapat memberikan penguatan terhadap hasil wawancara. Wawancara dilakukan secara terstruktur di mana pewawancara menentukan sendiri masalah dan pertanyaan yang diajukan. Dalam penelitian ini wawancara dilakukan sesuai pedoman wawancara yang telah ditentukan.

Tabel 1.

Pedoman Wawancara

\section{Kisi-kisi}

Pengelolaan waktu pada tiap individu menjadi inti dari karakteristik pertanyaan nomor 1 .

Pengelolaan diri terhadap Pernahkan anda merasa kerja sama dalam tim sulit untuk bekerja menjadi inti dari dengan anggota tim karakteristik pertanyaan lainnya secara virtual? nomor 2. Mengapa?

Pengelolaan tugas dalam Bagaimana cara anda kerja sama tim menjadi dan anggota tim anda inti dari karakteristik membagi tugas? pertanyaan nomor 3,4 .

\begin{tabular}{|c|c|}
\hline $\begin{array}{l}\text { Pengelolaan diri pada } \\
\text { kondisiatau suasana kerja } \\
\text { sama dalam tim menjadi } \\
\text { inti dari karakteristik } \\
\text { pertanyaan nomor } 5,6,7\end{array}$ & $\begin{array}{l}\text { Bagaimana cara anda } \\
\text { mengapresiasi hasil } \\
\text { pekerjaan teman anda? }\end{array}$ \\
\hline $\begin{array}{l}\text { Pengelolaan diriterhadap } \\
\text { kondisi perbedaan } \\
\text { pendapat dalam tim } \\
\text { menjadi inti dari } \\
\text { karakteristik pertanyaan } \\
\text { nomor } 8\end{array}$ & $\begin{array}{l}\text { Apa y a ng a nda } \\
\text { lakukan apabila terjadi } \\
\text { perbedaan pendapat } \\
\text { dalam mengerjakan } \\
\text { tugas sebagai tim? }\end{array}$ \\
\hline
\end{tabular}

Kemudian dilakukan keabsahan data untuk membuktikan bahwa penelitian ini merupakan penelitian ilmiah sekaligus menguji data yang didapatkan. Keabsahan data penelitian ini diuji menggunakan teknik triangulasi, transferability, dependability, dan konfirmability. Triangulasi adalah pengecekan data dari berbagai sumber yang dalam penelitian ini menggunakan sumber hasil wawancara dan observasi partisipasi (Sugiyono, 2016). Uji tranferabilitas yaitu validitas eksternal di mana berkaitan dengan sejauh mana pertanyaan pada penelitian dapat digunakan dalam situasi lain. Uji dependabilitas atau reliabilitas dilakukan dengan melakukan pemeriksaan keseluruhan proses penelitian. Sedangkan uji konfirmabilitas disebut uji objektivitas yakni hasil penelitian telah disepakati oleh banyak orang atau banyak orang yang menyetujui hasil penelitian yang didapatkan.

Teknik analisis data yang digunakan adalah model Miles dan Huberman yang terdiri atas aktivitas data reduction, data display, dan drawing/verification. Reduksi data dalam penelitian ini dilakukan dengan memilih hal-hal pokok dan memfokuskan pada hal penting berdasarkan hasil wawancara. Penyajian data dilakukan dengan membuat teks narasi dan uraian singkat dari hasil wawancara agar dapat dipahami. Kemudian peneliti melakukan verifikasi data dengan menarik kesimpulan dari hasil penyajian data.

Pemeriksaan terhadap keabsahan data pada dasarnya, selain digunakan untuk menyanggah balik yang dituduhkan kepada penelitian kualitatif yang mengatakan tidak ilmiah, juga merupakan sebagai unsur yang tidak terpisahkan dari tubuh pengetahuan penelitian kualitatif (Hadi, 2016). Penerapan derajat kepercayaan (credibility) pada penelitian ini menggunakan triangulasi peneliti dan mengadakan member check.

Shidiq \& Choiri (2019) mengatakan triangulasi dalam pengujian kredibilitas diartikan sebagai pengecekan data dari berbagai sumber dengan berbagai waktu. Triangulasi peneliti yaitu menggunakan lebih dari satu peneliti dalam mengadakan wawancara atau observasi. Triangulasi peneliti dimaksudkan antara lain untuk menghindari potensi bias individu pada peneliti tunggal. Pada penelitian ini, terdapat empat peneliti yang melakukan wawancara terhadap informan dan pengamatan selama pelaksanaan pertukaran pelajar. Data yang dikumpulkan selanjutnya diolah bersama sehingga menjadi data yang siap digunakan.

Selanjutnya peneliti mengadakan member check. Tujuan member check yaitu supaya informasi yang diperoleh dan akan digunakan dalam penulisan laporan sesuai dengan apa yang dimaksud sumber data atau informan (Sondak et al., 2019). Dalam hal ini peneliti melakukan pengecekan terhadap data yang sudah diperoleh dari pemberi data, apakah data yang diberikan oleh pemberi data sudah memenuhi kebenaran atau valid.

\section{HASIL DAN PEMBAHASAN}

\section{Hasil}

Pada awal percakapan dengan mahasiswa pertukaran pelajar yang menjadi partisipan penelitian, ditanyakan mengenai apa yang mereka ketahui 
mengenai self management? Sebagian besar menjawab bahwa yang mereka ketahui mengenai self management adalah kemampuan untuk mengendalikan diri, terhadap segala kegiatan yang dilakukan.

Berikut ini adalah petikan wawancara yang dilakukan oleh peneliti dan partisipan penelitian. Pada petikan wawancara tersebut, " $\mathrm{P}$ " selaku peneliti dan "M" sebagai informan. Di bawah ini merupakan petikan wawancara pada pertanyaan awal :

P : "Apa yang kamu ketahui tentang self management?"

M1 : "Pengendalian diri. Artinya cara saya untuk mengendalikan apa yang akan saya katakan atau perbuat sehingga mengurangi resiko terjadinya sesuatu yang tidak diinginkan"

M2 : "Self management merupakan suatu kemampuan yang dimiliki untuk mengendalikan diri sendiri baik cara bertindak, cara berbicara, pemikiran, dan lain sebagainya."

Penelusuran selanjutnya terhadap jawaban tersebut adalah mengenai bagaimana self management mahasiswa pertukaran pelajar selama ini. Sebagian mahasiswa menjawab sudah cukup baik karena mereka membuat perencanaan apa yang akan mereka kerjakan sesuai dengan prioritas. Sebagian lagi menjawab belum cukup baik, tetapi mereka terus berlatih sehingga kedepannya bisa lebih baik lagi.

Berikut adalah petikan wawancara dari pertanyaan mengenai bagaimana self management diri pada mahasiswa pertukaran pelajar antar universitas.

$\mathrm{P} \quad$ : "Bagaimana self management mu selama ini?"

M1 : "Sudah baik. Dapat membagi waktu antara kegiatan perkuliahan dengan kegiatan lain di luar perkuliahan. Dapat menentukan prioritas dalam menyelesaikan tugas. Selalu mengutamakan urusan kuliah terlebih dahulu."

M2 : "Belum cukup baik karena saya orang yang impulsif. Tapi ketika saya gagal mengendalikan diri disitu saya belajar untuk lebih memperhatikan self management saya sehingga kedepannya saya tidak gagal lagi."

Self management mahasiswa pertukaran pelajar sebagian sudah baik, karena mereka membuat perencanaan dan urutan prioritas untuk setiap kegiatan yang dilakukan. Sebagian lagi self management-nya kurang baik, tetapi mereka selalu melatih diri mereka agar lebih baik lagi.
1. Pengerjaan tugas kelompok dahulu, sehingga anggota tim dapat bekerja sama

Berikut adalah hasil wawancara dari pertanyaan cara membagi waktu untuk pekerjaan individu dan pekerjaan kelompok :

P : "Bagaimana cara kamu membagi waktu dalam mengerjakan pekerjaan individu dan kelompok?"

M1 : "Biasanya saya mengerjakan tugas individu terlebih dahulu karena lebih efektif karena hanya melibatkan diri saya sendiri. Baru kemudian tugas kelompok yang membutuhkan waktu untuk berdiskusi terlebih dahulu baru mengerjakan"

M2 : "Mengerjakan sesuatu yang dianggap mudah terlebih dahulu, entah itu merupakan pekerjaan individu atau pekerjaan kelompok."

M3 : "Saya sering mendahulukan tugas kelompok daripada tugas individu, tetapi tergantung dengan tenggang waktu pengumpulan tugas yang diberikan. Saya juga sering multitasking dalam mengerjakan tugas sebelum akhirnya saya bisa fokus pada satu tugas yang saya rasa penting untuk diselesaikan terlebih dahulu."

Cara pembagian waktu yang dilakukan oleh mahasiswa pertukaran pelajar cukup beragam, ada yang menyelesaikan tugas individu terlebih dahulu karena tidak perlu berdiskusi dengan orang lain dan hanya melibatkan diri sendiri. Ada yang memilih mengerjakan yang dirasa mudah terlebih dahulu. Dan ada juga yang memilih mengerjakan tugas kelompok karena melibatkan banyak orang.

Cara pembagian waktu dalam mengerjakan pekerjaan individu dan pekerjaan kelompok setiap orang berbeda-beda, tetapi tetap harus melihat mana yang harus yang harus diutamakan. Tugas yang diutamakan adalah yang memiliki deadline terdekat.

2. Kesibukan pribadi menjadi pendorong anggota tim untuk saling berdiskusi

Berikut adalah petikan wawancara dari pertanyaan apakah pernah merasa sulit bekerja kelompok secara virtual :

P : "Pernahkan anda merasa sulit untuk bekerja dengan anggota tim lainnya secara virtual? Mengapa?" 
M1 : "Pernah karena secara virtual tidak semua pendapat bisa tersampaikan dan kadang bisa terjadi kesalahpahaman dan miskomunikasi"

M2 : "Pernah. melakukan kerja kelompok secara virtual memiliki kesulitan tersendiri. diluar forum, setiap anggota memiliki kesibukan tersendiri dan sulit menemukan waktu yang pas untuk benar-benar dapat melakukan diskusi secara bersamaan."

Hampir semua informan menjawab pernah mengalami kesulitan saat bekerja kelompok. Kesulitan-kesulitan tersebut dikarenakan pengerjaan tugas secara virtual seringkali terjadi miskomunikasi, setiap anggota kelompok memiliki kesibukan tersendiri, tidak semua pendapat tersampaikan dan terkadang terkendala sinyal.

3. Pembuatan kerangka tugas untuk membagi penugasan kelompok agar adil

Berikut adalah hasil wawancara dari pertanyaan cara membagi tugas dengan tim.

P : "Bagaimana cara anda dan anggota tim anda membagi tugas?"

M1 : "Kami membuat kerangka tugas yang akan kami kerjakan terlebih dahulu, membahas secara garis besar baru membagi poin-poin yang harus dikerjakan secara individu."

M2 : "Kebanyakan tugas yang dilakukan secara berkelompok dibagi bagian pengerjaannya secara acak. Kemudian hasil pekerjaan tersebut dibahas kembali secara bersama-sama"

Semua informan menjawab cara pembagian tugas dengan anggota tim dilakukan dengan membagi tugas. Pembagian tugas ini bisa dilakukan setelah membahas kerangka tugas dan poin-poin mana yang harus dikerjakan oleh setiap anggota tim. Pembagian tugas ini dilakukan secara acak. Setelah semua tim menyelesaikan tugasnya, hasil pekerjaan tersebut digabung dan dibahas bersamasama.

Berikut adalah hasil wawancara mengenai penggunaan timeline dalam pembagian tugas tim.

P : "Apakah dalam pembagian tugas tim anda menggunakan timeline?"
M1 : "Terkadang dalam pembuatan tugas diberikan deadline pengumpulan masing-masing bagian sehingga setelah setiap bagian selesai, dapat disusun menjadi satu kesatuan dan didiskusikan bersama."

M2 : "Timeline yang kami buat tidak spesifik dan terorganisir. Waktu yang biasanya ditentukan adalah waktu untuk mengumpulkan tugas, sehingga bisa digabungkan sebelum deadline tugas."

Berdasarkan hasil wawancara tersebut, sebagian besar informan menjawab bahwa mereka selalu menggunakan timeline dalam pembagian tugas tim/kelompok. Timeline yang digunakan berupa penentuan tanggal pengumpulan tugas setiap mahasiswa yang kemudian digabung menjadi tugas kelompok. Menurut beberapa informan, penggunaan timeline dapat membantu mempercepat penyelesaian tugas, sehingga tugas tim dapat selesai tepat waktu. Namun, terdapat dua informan yang mengaku jarang mengaku tidak selalu atau jarang menggunakan timeline dalam pembagian tugas tim.

4. Komunikasi yang baik antar anggota tim membuat kinerja tim meningkat

Berikut adalah hasil wawancara mengenai tanggapan apabila anggota tim tidak menyelesaikan pekerjaannya sesuai timeline.

P : "Bagaimana tanggapan anda dan anggota tim anda apabila terdapat anggota tim yang pekerjaannya tidak selesai sesuai timeline?"

M1 : "Menegurnya dan memberi tahu bahwa besok tidak boleh telat mengumpulkan bagiannya karena dapat menyulitkan kelompok."

M2 : "Kami akan memintanya untuk segera menyelesaikan tugas melalui WA atau telepon, jika memang tidak ditanggapi maka akan dibantu oleh anggota lain tetapi tetap anggota yang tidak sesuai timeline akan diberikan tugas lain."

Berdasarkan hasil wawancara terdapat beragam jawaban informan. Keberagaman jawaban ini membuktikan bahwa pemikiran dan perilaku setiap mahasiwa berbeda-beda. Diketahui bahwa tiga partisipan menjawab akan meminta anggota tim tersebut untuk segera menyelesaikan tugasnya. Tiga informan akan mengomunikasikan dengan 
kelompok. Dua informan akan memberi toleransi terhadap anggota tersebut. Satu informan mengaku akan menegurnya dan memberi peringatan bahwa tidak boleh telat mengumpulkan bagiannya karena dapat menyulitkan kelompok. Satu informan menjawab bahwa akan memberi bantuan dan satu informan beranggapan bahwa anggota tersebut tidak bertanggung jawab terhadap tugasnya.

Berikut adalah hasil wawancara mengenai cara anggota tim mengapresiasi pekerjaan anda.

\section{P : “Bagaimana cara anggota tim anda mengapresiasi pekerjaan anda ataupun teman yang lain?" \\ M1 : "Jika pekerjaan saya kurang tepat atau kurang sesuai dengan topik yang diangkat, teman sekelompok selalu mengingatkan dan memberikan kritik dan saran sehingga saya dapat memperbaiki pekerjaan saya." \\ M2 : "Dengan mengatakan terima kasih dan tidak mengkritik dengan tanpa alasan tapi menilai apa yang kurang/terlewat dari pekerjaan saya."}

Sebagian besar informan mengaku diberi ucapan terimakasih atas pekerjaan yang sudah dilakukan yang disertai dengan kritik dan saran. Satu informan menjawab diberi kata penyemangat dan penguatan. Satu informan mengaku selalu diingatkan oleh teman sekelompok, sehingga dapat memperbaiki pekerjaannya dan terdapat satu informan yang selalu mendapatkan sticker Whatsapp yang lucu sebagai wujud ucapan terimakasih.

Berikut adalah hasil wawancara mengenai cara anda mengapresiasi hasil pekerjaan teman.

P : “Bagaimana cara anda mengapresiasi hasil pekerjaan teman anda?"

M1 : "Sekedar mengucapkan terimakasih atau menggunakan sticker di WA untuk memberikannya semangat, memberikan saran apabila diperlukan, yang paling penting adalah respon dari diri kita selaku anggota kelompok karena terkadang respon juga mempengaruhi kinerja individu"

M2 : "Memuji pekerjaan dia dan melakukan reinforcement."

M3 : "Saya akan membaca dan mengamati hasil pekerjaan teman, kemudian mengucapkan terimakasih."

Sebagian besar informan mengaku bahwa apresiasi berbentuk ungkapan verbal, yaitu "terimakasih." Tiga informan akan memuji pekerjaan temannya. Dua informan akan memberi masukan berupa kritik dan saran. Satu informan memberikan penyemangat atas pekerjaan yang sudah diselesaikan. Satu informan mengaku akan membaca dan mengamati pekerjaan temannya tersebut sebagai bentuk apresiasi.

5. Musyawarah guna pemecahan masalah, sehingga kinerja tim tetap terjaga

Berikut adalah hasil wawancara pertanyaan mengenai tindakan apabila terjadi perbedaan pendapat dalam mengerjakan tugas sebagai tim.

P : "Apa yang anda lakukan apabila terjadi perbedaan pendapat dalam mengerjakan tugas sebagai tim?"

M1 : "Saya selalu meminta teman-teman kelompok untuk mengecek pekerjaan yang telah saya kerjakan untuk menghindari kesalahan dan perbedaan pendapat. jika ada perbedaan pendapat, saya akan menerima masukan kelompok dan menyesuaikannya dengan hasil pekerjaan saya."

M2 : "Perbedaan pendapat dilanjutkan dengan diskusi untuk mencari solusi dari perbedaan pendapat tersebut. Kami memilih salah satu pendapat yang masuk akal atau mencari titik tengah dari perbedaan pendapat itu."

Sebagian besar partisipan menjawab bahwa perbedaan pendapat diselesaikan dengan mencari jalan tengah melalui musyawarah atau diskusi. Terdapat satu informan memilih untuk mencari jalan keluar terbaik dengan menelaah konsekuensi terkecil. Satu partisipan menjawab bahwa Ia akan menerima masukan kelompok dan menyesuaikannya dengan hasil pekerjaannya.

Berdasarkan hasil triangulasi peneliti dan pengadaan member check ditemukan bahwa data yang didapat memiliki derajat kepercayaan yang tinggi. Triangulasi peneliti yang dilakukan oleh empat peneliti menunjukkan jawaban yang konsisten dari informan. Selain itu, pengadaan member check yang dilakukan juga membuktikan tidak adanya misscomunication antara peneliti dengan partisipan. Oleh karena itu, dapat dikatakan jika data yang dijadikan sumber penulisan artikel ini valid.

\section{Pembahasan}

Pembahasan hasil penelitian ini akan difokuskan pada analisis kemampuan self management mahasiswa kedua perguruan tinggi ini dalam membentuk suatu 
solid-teamwork secara daring dalam kegiatan Merdeka Belajar Kampus Merdeka Pertukaran Pelajar. Analisis kemampuan self management ini dilihat dari berbagai hal baik dari pengelolaan waktu, pengelolaan diri terhadap kerja sama dalam tim, pembagian tugas kepada anggota tim dan pengelolaan diri untuk menghadapi situasi pada tim. Aspek yang diperhatikan dalam menganalisis self management ini serupa dengan penelitian Muratama (2018) yang meningkatkan kemampuan disiplin dan tanggung jawab belajar siswa dengan memperhatikan kemampuan self management yang meliputi pemantauan diri, penguatan positif, perjanjian pada diri sendiri dan penguasaan terhadap rangsangan. Analisis juga dilihat dari beberapa parameter dalam membentuk solid teamwork. Indikator ini juga digunakan dalam penelitian yang dilakukan oleh Lawasi \& Triatmanto (2017) yang mengukur kerjasama tim pada karyawan perusahaan melalui indikator kerjasama, kepercayaan dan kekompakan.

Hasil penelitian menunjukkan sebagian besar informan sudah memahami mengenai Pengelolaan diri. Namun beberapa informan masih belum bisa mengatur manajemen diri sendiri. Hal tersebut dapat mempengaruhi hasil dari pekerjaan maupun kehidupan sosialnya, seperti hasil pekerjaan dalam sebuah kelompok (Jawward, 2007). Pernyataan tersebut didukung dengan hasil penelitian oleh Jazimah (2015) yang menjelaskan bahwa regulasi atau pengaturan diri digunakan untuk memecahkan masalah akademik sekaligus masalah-masalah sosial. Dengan demikian, self management sangatlah penting dan harus dimiliki oleh setiap mahasiswa dalam menyelesaikan pekerjaan termasuk tugas kelompok ataupun masalah yang dihadapinya.

Hampir seluruh informan memiliki perspektif kesulitan dalam membangun kerja sama kelompok secara virtual. Penyebab keadaan ini, di mana setiap mahasiswa memiliki jadwal yang berbeda-beda dan seringkali penyampaian pendapat kurang maksimal. Keadaan ini juga seringkali terkendala oleh jaringan internet di masing-masing daerah yang terkadang down, sehingga pelaksanaan pekerjaan kelompok kurang maksimal.

Hal ini serupa dengan penyampaian hasil penelitian oleh Anugrahana (2020) yang menyatakan tentang hambatan dalam pembelajaran daring atau virtual diantaranya adalah kurangnya keaktifan peserta didik dan susah sinyal. Komunikasi yang dilakukan secara virtual memberikan peluang kepada beberapa mahasiswa untuk tidak turut andil dalam melakukan diskusi dalam tim. Kendala susah sinyal pun juga menjadi penyebab kesulitan dalam menjalin kerja sama pada tim.

Seorang pendidik tentu akan mempersiapkan dan melakukan berbagai metode atau cara agar peserta didiknya tidak bosan dan tetap memiliki motivasi belajar yang tinggi. Banyak metode pembelajaran daring atau virtual yang dapat dilakukan pendidik antara lain diskusi, kuis, video, penugasan individu maupun kelompok. Pada hasil penelitian Mustakim (2020) menyatakan bahwa penugasan kelompok mendapat persentase terendah dalam survei metode pembelajaran yang disukai dalam pembelajaran daring. Hal ini menunjukkan bahwa kurangnya motivasi instrinsik dari peserta didik atau mahasiswa untuk melakukan kerja sama dalam tim. Hal tersebut didukung dengan hasil penelitian oleh Rosali (2020) yang menyatakan bahwa dalam komunikasi antar peserta didik maupun pendidik dengan peserta didik secara daring kurang berjalan dengan lancar dan belum maksimal yang menyebabkan mahasiswa atau peserta didik menjadi sulit memahami materi dan diskusi baik secara klasikal ataupun kelompok kurang intensif. Pernyataan tersebut menunjukkan bahwa komunikasi dalam menjalin kerja sama dalam tim yang dilakukan secara virtual masih belum maksimal dan kurang efektif.

Deadline tugas individu yang berbeda-beda juga menjadi kendala dalam pelaksanaan kegiatan kelompok. Dalam mengatasi hal tersebut, para informan mengomunikasikan terlebih dahulu kerangka materi tugas dan garis besar tugas yang akan dibahas secara bersama-sama sehingga memiliki satu tujuan dan tidak terjadi miscommunication. Selanjutnya pembagian dari tugasnya dikerjakan secara individu yang kemudian akan dikumpulkan untuk dibahas secara bersama-sama mengenai kesesuaian antara pekerjaan yang satu dan lainnya dengan tujuan kegiatan kelompok tersebut.

Rencana penyelesaian tugas yang dilakukan tersebut menunjukkan bahwa informan memiliki kemampuan self management yang baik. Hal ini serupa dengan Masram \& Mu'ah (2015) yang menyatakan bahwa kategori seseorang yang kemampuan pengaturan diri dalam belajar baik diantaranya adalah penyusunan tujuan dan perencanaan langkah, waktu serta penyempurnaan kegiatan sesuai dengan tujuan.

Perencanaan penyelesaian tugas yang disusun secara sistematik mendukung pendapat Tantri (2018) yang menjelaskan bahwa dalam kerja sama pada tim dalam pembelajaran daring mendorong proses kolaborasi yang mendorong pembelajar untuk mengonstruksi dan menyepakati arti pembelajaran 
ataupun cara untuk menyelesaikan tugas yang ada antara satu pembelajar dengan pembelajar lainnya. Hal ini menunjukkan bahwa dalam pembelajaran dalam jaringan mahasiswa tetap melakukan hubungan sosial terutama dalam kerja sama tim walaupun menggunakan media komunikasi yang memanfaatkan teknologi dan internet yang berupa teks maupun video conference. Chudari (2016) menjelaskan bahwa pada seseorang yang memiliki kecakapan self management yang baik maka akan tumbuh pada dirinya kecerdasan sosial yang berhubungan dengan kemampuannya berinteraksi dan bekerja sama secara baik dengan orang lain.

Pernyataan tersebut menunjukkan bahwa hubungan sosial yang terjalin dengan baik antar mahasiswa yang terbentuk dalam kerja sama tim menunjukkan adanya kemampuan pengelolaan diri yang baik pada mahasiswa. Pembagian tugas dengan menggunakan timeline akan mempermudah anggota tim dalam mengatur waktu dalam menyelesaikan tugas tersebut. Menurut Sundari \& Rofiah (2018) dengan menggunakan metode timeline (garis waktu), pelajar memiliki keaktifan dalam belajar, daya ingat yang lebih tinggi, pemahaman konsep yang lebih besar, serta dapat mengaplikasikan konsepkonsep yang dipelajari untuk kebutuhan sehari-hari. Dengan menggunakan timeline maka pekerjaan akan terorganisir dan terpantau sejauh mana pengerjaan tugas tersebut dan tugas akan selesai dengan tepat waktu.

Dalam menetapkan timeline, diperlukan time management yang baik di setiap tim. Gea (2014) menyebutkan bahwa time management adalah tentang perencanaan hari/waktu supaya bisa melakukan penggunaan paling baik atas waktu yang dimiliki. Penerapan time management sangat diperlukan untuk mendukung terjadinya efisien dibagi pengontrolan kemajuan yang dicapai, untuk menjadwal, dan menjalankan apa yang telah disepakati oleh anggota tim. Time management memiliki peran penting dalam menentukan timeline pada pengerjaan tugas. Time management yang baik dapat membantu semua anggota tim menyelesaikan tugasnya dengan tepat waktu atau sesuai timeline yang ditentukan.

Pada pengerjaan tugas yang tidak sesuai timeline, maka anggota tersebut diberi peringatan untuk segera menyelesaikan tugasnya. Namun, apabila salah satu anggota mengalami kesulitan dalam pengerjaan tugas sesuai timeline, maka anggota lain akan membantunya. Sundari \& Rofiah (2018) menyatakan bahwa pembuatan garis waktu bertujuan agar pendidik atau mahasiswa mampu menyelesaikan tugasnya sesuai kesepakatan sekaligus melatihnya untuk berpikir kronologis dan sistematis dalam menyelesaikan permasalahan.

Hal ini menunjukkan penggunaan timeline dalam pengerjaan tugas sangatlah bermanfaat. Namun jika terdapat anggota kelompok yang kesulitan menyelesaikan tugas sesuai waktu yang ditetapkan maka kemungkinan orang tersebut mengalami masalah sehingga anggota kelompok lainnya dapat membantu individu tersebut.

Selanjutnya, anggota tim yang telah menyelesaikan tugas diberi apresiasi agar lebih semangat untuk menyelesaikan tugas-tugas selanjutnya. Apresiasi tidak harus diberikan dalam wujud benda, tetapi bisa juga diberikan dalam bentuk pujian, ucapan selamat, atau ungkapan kebanggaan. Pada penelitian ini, informan mengungkapkan apresiasi dengan ucapan terimakasih dan kata-kata penyemangat. Dengan apresiasi tersebut anggota tim dapat merasakan lebih yakin dengan hasil pekerjaannya dan merasa lebih dihargai.

Sebuah tim yang beranggotakan beberapa orang dengan karakteristik yang berbeda-beda seringkali menyebabkan perbedaan pendapat dalam pengerjaan tugas. Pada penelitian ini, perbedaan pendapat sering terjadi ketika menjawab pertanyaan yang melibatkan pemikiran kritis mahasiswa. Namun, perbedaan pendapat ini dapat diatasi dengan musyawarah untuk mencari jalan tengah mengenai persoalan tersebut. Menurut Yani (2016) musyawarah merupakan kegiatan berupa tukar menukar gagasan untuk memecahkan suatu permasalahan sehingga muncul kesepakatan yang dapat diterima oleh anggota forum. Pada kegiatan musyawarah, setiap anggota tim saling menghargai pendapat satu dengan yang lainnya dan tidak memaksakan pendapatnya sendiri. Pengambilan keputusan dalam sebuah tim dilakukan berdasarkan kesepakatan bersama melalui berbagai pertimbangan.

Self management yang terdapat dalam diri setiap anggota tim akan berguna dalam proses pelaksanaan kegiatan agar berjalan dengan efektif dan maksimal. Dari hasil penelitian tersebut sebagian mahasiswa sudah memiliki self management yang baik karena mereka memiliki perencanaan dan prioritas kegiatan yang akan dilaksanakan. Manurung (2013) mengemukakan bahwa indikator-indikator kerja sama tim yang baik adalah kerja sama, kepercayaan dan kekompakan. Indikator-indikator tersebut sudah tampak dalam tim mahasiswa pertukaran pelajar antar perguruan tinggi.

Indikator kerja sama tim yang baik yang pertama adalah kerja sama. Berdasarkan hasil wawancara, dapat dilihat bahwa tidak semua tugas dalam kelompok 
dikerjakan secara bersama-sama, melainkan dibagi secara rata pada setiap anggota kelompok. Hal tersebut terlihat saat mahasiswa mendiskusikan kerangka maupun poin-poin tugas yang akan dikerjakan, dan kemudian membaginya. Saat tugas tersebut sudah selesai, maka akan dibahas secara bersama-sama untuk mengecek apakah sudah sesuai dengan apa yang diharapkan. Pada saat inilah anggota tim harus memahami tugas dan tanggungjawabnya.

Hasil kinerja kelompok akan meningkat apabila setiap anggota tim dapat memahami tugas dan tanggung jawabnya masing-masing serta berusaha melaksanakan tugas tersebut dengan sebaik-baiknya. Hal ini didukung oleh Marnung dalam Widyaswari \& Ruhana (2016), yang menyatakan bahwa kerjasama dalam tim akan menjadikan suatu daya dorong yang memiliki sinergisitas bagi setiap individu-individu yang tergabung dalam kerjasama tim.

Kemampuan dari setiap anggota dalam menyelesaikan tugasnya akan berdampak pada kinerja anggota lainnya. Individu-individu yang terampil apabila dapat bekerja secara bersamasama mengikuti pola dan sistem yang teruji akan membentuk kerjasama dalam pencapaian target dan tujuan bersama. Kemampuan tersebut merupakan salah satu bentuk Pengelolaan diri yang diperlukan dalam membentuk suatu tim yang solid. Hasil analisis ini mendukung penelitian sebelumnya yang telah dilakukan oleh Groeneveld \& Kuipers (2013), yang menunjukkan bahwa kerjasama eksternal berpengaruh positif terhadap manajemen diri. Hal tersebut menunjukkan bahwa apabila kerjasama dalam suatu tim itu baik maka manajemen diri dari masing-masing anggota tim tersebut baik pula.

Indikator kedua dari kerja sama tim yang baik adalah kepercayaan. Kepercayaan terhadap anggota dalam tim terhadap apa yang dikatakan dan yang dilakukan. Indikator ini terihat saat mahasiswa pertukaran pelajar menyelesaikan pekerjaan dengan pembagian tugas. Dalam hal ini terlihat bahwa setiap anggota tim percaya terhadap kemampuan anggota tim lainnya. Kepercayaan anggota tim terhadap anggota lainnya mempengaruhi kerjasama dalam tim. Hal ini sejalan dengan penelitian Natoil dan Zulkifli (2020) yang menyatakan bahwa apabila kepercayaan yang semakin tinggi, maka kerjasama tim semakin tinggi.

Indikator ketiga yaitu kekompakan. Menurut Hardiyati (2017) Kekompakan adalah bekerja sama secara teratur dan rapi, bersatu padu dalam menghadapi suatu pekerjaan yang biasanya ditandai adanya saling ketergantungan. Indikator ini terlihat pada saat pembagian tugas mahasiswa pertukaran pelajar antar perguruan tinggi menggunakan timeline. Dengan penggunaan timeline maka tugas akan terorganisir dan terpantau sejauh mana pengerjaan tugas tersebut. Kekompakan tim akan menghasilkan kinerja tim yang lebih baik. Hal ini didukung oleh pernyataan Kusuma \& Sutanto (2018) kekompakan antar anggota akan mempermudah dalam menyelesaikan suatu masalah, sehingga dapat menghasilkan kinerja yang lebih meningkat.

Kerja sama yang baik terjadi apabila terdapat kepercayaan dan kekompakkan dalam suatu tim. Kerja sama yang baik dapat dilihat juga dari cara berkomunikasi antar anggota kelompok tersebut sehingga tidak terjadi misscommuncation. Komunikasi yang terjalin dengan baik antar anggota tim mempengaruhi kinerja tim. Hal ini sesuai dengan pendapat Lawasi \& Triatmanto (2017) yang menyatakan bahwa semakin baik komunikasi yang dibina, maka semakin optimal kinerja karyawan untuk menjalankan tugasnya.

Jadi, dapat disimpulkan bahwa Pengelolaan diri sangat penting untuk membangun sebuah solid teamwork dalam Program Pertukaran Pelajar Antar Perguruan Tinggi ini. Apabila Pengelolaan diri mahasiswa kurang baik, maka hal tersebut akan mempengaruhi kerja sama tim yang baik (solid teamwork) pula menjadi kurang maksimal. Berlaku pula sebaliknya, jika pada diri mahasiswa memiliki kemampuan self management yang baik, maka kinerjanya dalam tim akan maksimal dan kerja samanya pada anggota tim dapat terjalin dengan baik.

\section{PENUTUP}

\section{Kesimpulan}

Hampir seluruh partisipan penelitian memiliki perspektif kesulitan dalam membangun kerja sama kelompok secara virtual. Hal tersebut dikarenakan setiap mahasiswa memiliki jadwal yang berbedabeda dan seringkali penyampaian pendapat kurang maksimal. Keadaan ini juga seringkali terkendala oleh jaringan internet di masing-masing daerah yang terkadang down.

Cara yang mahahasiswa lakukan untuk mengatasi hal tersebut adalah dengan memanajemen diri sendiri. Manajemen diri para mahasiswa sudah baik. Hal ini terlihat dari cara mereka membagi waktu antara pengerjaan tugas individu, tugas kelompok, dan kegiatan lain yang mereka lakukan. Pengerjaan tugas menggunakan timeline juga merupakan salah satu indikator dalam Pengelolaan diri. Mahasiswa juga menunjukkan komunikasi yang baik antar anggota 
kelompok sehingga tidak terjadi kesalahpahaman. Hal tersebut juga merupakan indikator Pengelolaan diri yang baik dalam hal sosial.

Kekompakkan tim terjadi saat setiap anggota bekerja sama dengan rapi dan teratur dalam menyelesaikan suatu tugas ditandai adanya saling ketergantungan. Indikator ini terlihat pada saat pembagian tugas mahasiswa pertukaran pelajar menggunakan timeline. Dengan penggunaan timeline maka tugas akan terorganisir dan terpantau sejauh mana pengerjaan tugas tersebut. Kerja sama yang baik terjadi apabila terdapat kerja sama, kepercayaan dan kekompakkan dalam suatu tim. Kerja sama yang baik dapat dilihat juga dari cara berkomunikasi antar anggota kelompok tersebut sehingga tidak terjadi misscommuncation.

Jadi, dapat disimpulkan bahwa Pengelolaan diri sangat penting untuk membangun sebuah solid teamwork dalam Program Pertukaran Mahasiswa dua universitas negeri di Jawa ini. Apabila Pengelolaan diri mahasiswa kurang baik, maka hal tersebut akan mempengaruhi kerja sama tim yang baik (solid teamwork) pula.

\section{Saran}

Para mahasiswa hendaknya memiliki self management atau pengelolaan diri dengan baik karena akan berakibat pada kinerjanya dalam suatu tim. Selain itu, self management pada diri mahasiswa juga berdampak pada kerja sama yang terbentuk dalam suatu tim. Agar kerja sama dapat terbentuk dengan baik sekaligus mampu menyelesaikan tugas dengan optimal maka dibutuhkanlah self managementself management yang baik pula bagi tiap diri mahasiswa.

\section{DAFTAR PUSTAKA}

Aboalshamat, K., Hou, X.-Y., \& Strodl, E. (2014). Selfdevelopment, Self-help, Human-development, Coaching, Motivational speaking, Psychological well-being; Self-development, Self-help, Human-development, Coaching, Motivational speaking, Psychological well-being. International Journal of Psychology and Behavioral Sciences, 4(4), 136-145. DOI: 10.5923/j.ijpbs.20140404.04

Anugrahana, A. (2020). Hambatan, Solusi dan Harapan: Pembelajaran Daring Selama Masa Pandemi Covid-19 Oleh Guru Sekolah Dasar. Scholaria: Jurnal Pendidikan Dan Kebudayaan, 10 (3), 282-289. DOI: 10.24246/j.js.2020.v10. i3.p282-289

Apriyani, T. (30 Desember 2019). Mahasiswa Sebagai Agent of Change dalam Kehidupan Berbangsa dan Bernegara. Suara.com. Diakses pada 22 November 2020 di https:/ / yoursay.suara.com/ lifestyle/2019/12/30/163843/mahasiswasebagai-agent-of-change-dalam-kehidupanberbangsa-dan-bernegara?page $=$ all

Banwo, A. O., Du, J., \& Onokala, U. (2015). The Impact of Group Cohesiveness on Organizational Performance: The Nigerian Case. International Journal of Business and Management, 10 (6), 146-154. DOI: 10.5539/ijbm.v10n6p146

Briesch, A. M., \& Daniels, B. (2013). Using Pengelolaan diri Interventions to Address General Educarion Behavioral Needs: Assessment of Effectiveness and Feasibility. Psychology in the Schools, 50 (4). DOI: 10.1002/pits.21679.

Chudari, I. N. (2016). Program Pelatihan Pengelolaan Diri (Pengelolaan diri) Dengan Teknik Kognitif. Edusentris: Jurnal Ilmu Pendidikan dan Pengajaran, 3(3), 243-255. DOI: 10.17509/edusentris.v3i3.235

Elvina, S. N. (2019). Teknik Self Management dalam Pengelolan Strategi Waktu Kehidupan Pribadi Yang Efektif. Islamic Counseling: Jurnal Bimbingan Konseling Islam, 3(2), 123. DOI: 10.29240/jbk. v3i2.1058

Fatchurahman, M. (2017). Konseling Kelompok Gestalt dengan Reversal Technique Untuk Meningkatkan Pemahaman Tentang Pengelolaan diri dalam Belajar Peserta Didik Kelas VIII di DMP. Jurnal Bimbingan Dan Konseling, 3 (1), 19-25. Retrieved from http:// jurnal.umpalangkaraya.ac.id/ejurnal/suluh

Gea, A. A. (2014). Time Management: Menggunakan Waktu Secara Efektif dan Efisien. Humaniora, 5(2), 777. DOI: 10.21512/humaniora.v5i2.3133

Gillebaart, M. (2018). The "operational" definition of self-control. Frontiers in Psychology, 9(1231), 1-5. DOI: 10.3389/fpsyg.2018.01231

Groeneveld, S., \& Kuipers, B. S. (2014). Teamwork in the Public Cage: Antecedents of Pengelolaan diri of Teams in Public Organizations. Academy of Management Proceedings, 2014 (1), 12064. DOI: 10.5465/ambpp.2014.12064abstract

Hadi, S. (2016). Pemeriksaan Keabsahan. Jurnal Ilmu Pendidikan, 22 (1), 74-79. DOI: 10.17977/um025v1i12016p074

Hardiyati, F. (2017). Pengaruh Interpersonal Trust Terhadap Teamwork Pada Karyawan Pizza Hut Cabang Yogyakarta. Skripsi Tidak Diterbitkan. Semarang: Universitas Negeri Semarang. Retrieved from http://lib.unnes.ac.id/29951/

Jazimah, H. (2015). Implementasi Manajemen Diri Mahasiswa dalam Pendidikan Islam. 
MUDARRISA: Journal of Islamic Education, 6(2), 221. DOI: $10.18326 /$ mdr.v6i2.765

Kadiyono, A. L., \& Hafiar, H. (2017). Student participation in the tutoring program (comparative study between socio-economic schools high and low). Proceedings of the Asian Education Symposium (AES 2016), November 22-23, 2016, Bandung, Indonesia. Ideas for 21st Century Education, August 2017, 153-156. DOI: 10.1201/9781315166575-30

Kementerian Pendidikan dan Kebudayaan. (2020). Buku Panduan Merdeka Belajar - Kampus Merdeka. Jakarta: Direktorat Jenderal Pendidikan Tinggi Kemdikbud RI.

Khoiriyah, S. (2011). Pelatihan: Upaya Mempersiapkan Sumber Daya Manusia Yang Berkualitas Dalam Menghadapi Tantangan Globalisasi. Semarang: Gema Stikubank.

Kusuma, L. P., \& Sutanto, J. E. (2018). Peranan Kerjasama Tim dan Semangat Kerja terhadap Kinerja Karyawan Zolid Agung Perkasa. PERFORMA: Jurnal Manajemen Dan Start-Up Bisnis, 3. Retrieved from: https:/ /journal.uc.ac. $\mathrm{id/index.php/performa/article/view/754.}$

Lagu, M. (2016). Komunikasi Antar Budaya di Kalangan Mahasiswa Etnik Papua dan Etnik Manado di Universitas Sam Ratulangi Manado. Jurnal Acta Diurna, V (3), 1-10. Retrieved from https://ejournal.unsrat.ac.id/ index.php/actadiurnakomunikasi/article/ view/12774/12366

Lawasi, E. S., \& Triatmanto, B. (2017). Pengaruh komunikasi, motivasi dan kerjasama tim terhadap peningkatan kinerja karyawan. Jurnal Manajemen dan Kewirausahaan (JMDK), 5(1), 4757. DOI: 10.26905/jmdk.v5i1.1313

Masram, \& Mu'ah. (2015). Manajemen Sumber Daya Manusia. Zifatama Publisher. Diakses melalui http: / / www.stiekhad.ac.id/wp-content/ uploads/2018/02/BUKU-MSDM.pdf

Maxwell, S. M., et. al. (2014). Pragmatic Approaches For Effective Management Of Pelagic Marine Protected Areas. Journal of Applied Psychology,267, 59-74. DOI: 10.3354/esr00617

Muratama, M.S. (2018). Layanan Konseling Behavioral Teknik Self Management Untuk Meningkatkan Disiplin Dan Tanggung Jawab Belajar Siswa Di Sekolah. Nusantara of Research : Jurnal Hasil-Hasil Penelitian Universitas Nusantara PGRI Kediri, 5 (1), 1-8. DOI: 10.29407/nor.v5i1.11793

Mustakim. (2020). Efektivitas Pembelajaran Daring Menggunakan Media Online Selama Pandemi
Covid-19 Pada Mata Pelajaran Matematika the Effectiveness of E-Learning Using Online Media During the Covid-19 Pandemic in Mathematics. Al Asma: Journal of Islamic Education, 2 (1), 1-12. DOI: 10.24252/asma.v2i1.13646

Natoil, N., \& Zulkifli, Z. (2020). Peningkatan Kinerja Berbasis pada Kualitas Komunikasi, Kepercayaan dan Kerjasama Tim. Jurnal Capital: Kebijakan Ekonomi, Manajemen dan Akuntansi, 2 (1), 1-15. DOI: 10.33747/capital.v2i1.31

Nurwendah, W., \& Suyanto, S. (2019). Relationship among Self-Motivation, Self-Efficacy and Achievement of High School Student in Biology. Journal of Physics: Conference Series, 1-5. DOI: 10.1088/1742-6596/1233/1/012009

Rosali, E. S. (2020). Aktifitas Pembelajaran Daring Pada Masa Pandemi Covid -19 Di. Geography Science Education Journal (GEOSEE), 1(1), 21-30. Retrieved from https:/ / www.researchgate.net/ publication/340917125_Kendala_Pelaksanaan_ Pembelajaran_Jarak_Jauh_PJJ_dalam_Masa_ Pandemi/stats

Rosmilawati, I.. (2017). Learning through Individuation: How Indonesian Young People Seek a Personal Growth and Self-Development at Alternative Schooling. Journal of Nonformal Education, 3(2), 87-96. DOI: 10.15294/jne.v3i2.10943

Sanyal, S., \& Hisam, M. W. (2018). The Impact of Teamwork on Work Performance of Employees. IOSR Journal of Business and Management (IOSR-JBM), 20 (3), 15-22. DOI: 10.9790/487X2003011522

Setyarini, P. (2018). Pengaruh Kepribadian Terhadap Kerja sama Tim Melalui Komitmen Sebagai Variabel Intervening (Studi kasus Bank BTN Syariah Semarang). Skripsi Tidak Diterbitkan. Salatiga: IAIN Salatiga. Diakses melalui http://erepository.perpus.iainsalatiga.ac.id/2493/

Shidiq, U., \& Choiri, M. (2019). Metode Penelitian Kualitatif di Bidang Pendidikan. Journal of Chemical Information and Modeling, 53 (9). Retrieved from http:/ / repository.iainponorogo. ac.id/484/1/METODE PENELITIAN KUALITATIF DI BIDANG PENDIDIKAN.pdf

Sondak, S. H., Taroreh, R. N., \& Uhing, Y. (2019). Faktor-faktor Loyalitas Pegawai di Dinas Pendidikan Daerah Provinsi Sulawesi Utara. Jurnal EMBA: Jurnal Riset Ekonomi, Manajemen, Bisnis dan Akuntansi, 7 (1), 671-680. DOI: 10.35794/emba.v7i1.22478

Sugiyono. (2016). Metode Penelitian Kuantitatif, Kualitatif dan RED. Bandung: Alfabeta. 
Sun Education Group. (2020). Syarat Pertukaran Pelajar. Diakses pada 22 November 2020 di https:// suneducationgroup.com/app/sun-media-app/ news-app/syarat-pertukaran-pelajar/

Sundari, K \& Rofiah. (2018). Peningkatan Pemahaman Konsep Melalui Metode Timeline (Garis Waktu) Pada Mata Pelajaran Ilmu Pengetahuan Sosial (IPS) Kelas V SD Al-Wathoniyah Bekasi Timur. Journal Information, VI (1), 79-89. Retrieved from http://jurnal.unismabekasi.ac.id/index.php/ pedagogik/article/view/440

Tantri, N. R. (2018). Kehadiran Sosial Dalam Pembelajaran Daring Berdasarkan Sudut
Pandang Pembelajar Pendidikan Terbuka Dan Jarak Jauh. Jurnal Pendidikan Terbuka Dan Jarak Jauh, 19 (1), 19-30. DOI: 10.33830/ptjj. v19i1.310.2018

Widyaswari, U.H., \& Ruhana. (2016). Pengaruh Budaya Organisasi dan Gaya Kepemimpinan terhadap Kerjasama Tim. Jurnal Administrasi Bisnis, 2837. Retrieved from: http://administrasibisnis. studentjournal.ub.ac.id/index.php/jab/ article/view/1452.

Yani, T. A. (2016). Musyawarah sebagai Karakter Bangsa Indonesia. Community, 2(2), 165-174. DOI: 10.35308/jcpds.v2i2.135 